\title{
Structure and Mechanical Properties of Mg-Based Alloys for Elevated Temperature Applica- tions
}

Dalibor Vojtěch, Jiří Kubásek, Milena Voděrová, Jan Šerák

Department of Metals and Corrosion Engineering, Istitute of Chemical Technology, Prague, Technická 5, 16628 Prague 6, Czech Republic, E-mail: Dalibor.Vojtech@vscht.cz

\begin{abstract}
Magnesium alloys are progressive light-weight materials with a great potential in automotive and aerospace applications in which they enable significant weight and fuel savings. However, the main drawback of the most widely used $\mathrm{AZ}$ type magnesium alloys (Mg-Al-Zn) is a very poor thermal stability. The $\mathrm{AZ}$ alloys cannot be applied in components exposed to temperatures exceeding $120^{\circ} \mathrm{C}$, because of a rapid drop of mechanical characteristics at above this temperature. There are two approaches to improve the thermal stability of $\mathrm{Mg}$ alloys. The first one consists in alloying with rare earth metals and the second one involves simoultaneous additives of aluminium and alkaline earth metals $(\mathrm{Ca}, \mathrm{Sr})$. In the present study, microstructures, mechanical properties and thermal stability are characterized for advanced commercial Mg alloys, WE43 (MgY4Nd2RE1Zr) and AJ62 (MgAl6Sr2) developed for elevated temperature applications. It is semonstrated that thermal stability of both kinds of alloys significantly exceeds that of the commercial casting AZ91 (MgAl9Zn1) alloy.
\end{abstract}

Keywords: Magnesium, Mechanical Properties, Thermal Stability

\section{Acknowledgement}

Authors would like to thank the Czech Science Foundation (project no. P108/12/G043) for the financial support of this research.

\section{References}

[1] LICHÝ, P., BEŇO, J., CAGALA, M. (2013). Possibility of affecting the casting structure of magnesium alloys. In: Manufacturing Technology, Vol. 13, pp. 341-345. J. E. Purkyne University, Ústí nad Labem, Czech Republic.

[2] HLAVÁČOVÁ, I., PALČEK, P., CHALUPOVÁ, M. (2013). Plastic deformation properties of magnesium alloy AZ91. In: Manufacturing Technology, Vol. 13, pp. 313-319. J. E. Purkyne University, Ústí nad Labem, Czech Republic.

[3] BEŇO, J., LICHÝ, P., CAGALA, M., KONEČNÁ, K., BŘUSKA, M. (2013). Study of interactions between molding materials and magnesium alloys melt metal. In: Manufacturing Technology, Vol. 13, pp. 265-269. J. E. Purkyne University, Ústí nad Labem, Czech Republic.

[4] LICHÝ, P., BEŇO, J., CAGALA, M. (2013). Inoculant addition effect on thermomechanical and thermophysical properties of Mg-Sr magnesium alloy. In: Manufacturing Technology, Vol. 13, pp. 64-67. J. E. Purkyne University, Ústí nad Labem, Czech Republic.

[5] GALE, W.F., TOTEMEIER, T.C. (2004). Smithels Metals Reference Book. Elsevier, Amsterdam.

[6] KAINER, K.U. (2003). Magnesium - Alloys and Technologies. WILEY-VCH, Weinheim.

[7] YOO, M.K., KIM, J.J., SHIN, K.S., KIM, N.J. (2002). Effect of Second Phases on the High temperature mechanical Properties of squeeze cast Mg-Al alloys. In: Magnesium Technology, pp. 252-255. TMS, Warrendale.

[8] RZYCHON, T., KIELBUS, A. (2007). Microstructure of WE43 casting magnesium alloy. In: Journal of Achievements in Materials and manufacturing Engineering, Vol. 21, pp. 31-34. International OCSCO World Press, Poland.

[9] LYON, P. (2004). New magnesium alloy for aerospace and speciality applications. In: Magnesium Technology, pp. 311-315. TMS, Warrendale.

[10] ŽALUDOVÁ, N. (2005). Mg-RE alloys and their applications. In: WDS'05 Proceedings of Contributed Papers, Part III, pp. 643-648. MATFYZPRESS, Prague.

[11] YU, K., LI, W.X., WANG, R.C. (2008). Effects of T5 and T6 tempers on a hot rolled WE43 magnesium alloy. In: Materials Transactions, Vol. 49, pp. 1818-1821. JIM, Japan.

[12] KUNST, M., FISCHERSWORRING-BUNK, A. (2009). Microstructure and dislocation analysis after creep deformation of die-cast Mg-Al-Sr (AJ) alloy. In: Materials Science and Engineering A, Vol. 510-511, pp. 387-392. Elsevier, USA. 
[13] XU, L., LIU, C., WAN, Y., WANG, X. (2012). Effects of heat treatments on microstructures and mechanical properties of Mg-4Y-2.5Nd-0.7Zr alloy. In: Materials Science and Engineering A, Vol. 558, pp. 1-6. Elsevier, USA.

[14] MENGUCCI, P., BARRUCCA, G. (2008). Structure evolution of a WE43 Mg alloy submitted to different thermal treatments. In: Materials Science and Engineering A, Vol. 479, pp. 37-44. Elsevier, USA.

[15] NEUBERT, V., STUlíKOVÁ, I., SMOLA, B., MORDIKE, B.L., VLACH, M., BAKKAR, A. (2007). Thermal stability and corrosion behaviour of Mg-Y-Nd and MgTb-Nd alloys. In: Materials Science and Engineering A, Vol. 462, pp. 329-333. Elsevier, USA.

[16] BLUM, W., LI, Y., ZENG, X., ZHANG, P. (2005). Creep deformation mechanisms in high-pressure die-cast magnesium-aluminium-base alloys. In: Metallurgical and Materials Transactions A, Vol. 36, pp.1721-1728. ASM International, USA.

Copyright (C) 2014. Published by Manufacturing Technology. All rights reserved. 